Тестування в діагностиці розвитку когнітивного компонента готовності майбутніх учителів початкової школи до застосування засобів електронної лінгвометодики в професійній діяльності

УДК 371.315.6:51

\title{
ТЕСТУВАННЯ В ДІАГНОСТИЦІ РОЗВИТКУ КОГНІТИВНОГО КОМПОНЕНТА ГОТОВНОСТІ МАЙБУТНІХ УЧИТЕЛІВ ПОЧАТКОВОЇ ШКОЛИ ДО ЗАСТОСУВАННЯ ЗАСОБІВ ЕЛЕКТРОННОЇ ЛІНГВОМЕТОДИКИ В ПРОФЕСІЙНІЙ ДІЯЛЬНОСТІ
}

\section{Інна Хижняк}

доктор педагогічних наук, професор, декан факультету початкової, технологічної та професійної освіти, ДВНЗ «Донбаський державний педагогічний університет»,

м. Слов'янськ Донецької обл., Україна

http://orcid.org/0000-0002-4227-8268

innakhieshn@gmail.com

\begin{abstract}
Анотація. У статті обгрунтовано важливість діагностики розвитку професійних новоутворень майбутнього фахівця, одним із яких для вчителя початкової школи виступає готовність до застосування засобів електронної лінгвометодики в професійній діяльності та використання в цьому процесі методу тестування. Під час дослідження рівня розвитку цієї готовності в майбутніх учителів початкової школи автор спирається на потужну теоретичну базу, до якої увійшли традиційні вітчизняні тенденції в підготовці вчителя початкової школи, інновації в підготовці фахівців для початкової школи XXI ст., теоретичні засади лінгвометодичної підготовки майбутнього вчителя та теоретико-методичні основи електронної лінгвометодики. У статті автор дійшла висновку, що тестування $є$ релевантним методом вимірювання відповідного особистісного феномена майбутніх учителів і за умов традиційного навчання лінгвометодики в більшості майбутніх фахівців у галузі початкової освіти (і бакалаврів, і магістрів) переважає репродуктивний рівень розвитку когнітивного компонента готовності, а мінімальною є кількість респондентів, які виявили приналежність до дослідницько-креативного рівня. Ці показники дозволили автору вказати на необхідність системного опанування основ електронної лінгвометодики на бакалаврському та магістерському ступенях вищої освіти.
\end{abstract}

Ключові слова: педагогічна діагностика; тестування; електронна лінгвометодика; лінгвометодична компетентність; готовність до застосування засобів електронної лінгвометодики в професійній діяльності; учитель початкової школи.

Постановка проблеми в загальному вигляді. Упродовж останніх років вітчизняна система вищої освіти зазнає значних реформувань: визначені та законодавчо закріплені стратегічні напрями іiі розвитку, удосконалено системи та процедури контролю якості освіти (насамперед ліцензування, акредитація), затверджено систему стандартів, які містять вимоги до фахової компетентності та кваліфікаційну характеристику, системи діагностики якості знань тощо. Відтак для врахування сучасних i перспективних вимог суспільства до особистості та задоволення іï освітніх потреб необхідним $\epsilon$ визначення, моніторинг, коригування стратегічних пріоритетів і тактичних завдань розвитку освітньої галузі [7]. 
Тестування в діагностиці розвитку когнітивного компонента готовності майбутніх учителів початкової школи до застосування засобів електронної лінгвометодики в професійній діяльності

У цьому зв'язку важливим компонентом освітнього процесу педагогічного ЗВО постає діагностика розвитку професійних новоутворень майбутнього фахівця, одним із яких для вчителя початкової школи є готовність до застосування засобів електронної лінгвометодики в професійній діяльності. Метод тестування наразі є традиційним складником педагогічної діагностики, що найбільше виявляє свою ефективність під час вимірювання когнітивного компонента певного професійного феномена, зокрема й готовності майбутніх учителів початкової школи до застосування засобів електронної лінгвометодики в професійній діяльності.

Аналіз останніх досліджень і публікацій. Українська тестологія наразі перебуває в стані швидкоплинного розвитку, бо практика навчання на всіх щаблях освіти вимагає постійного контролю знань, умінь і навичок учнів $\mathrm{i}$ здобувачів. Існує чимала частка власне українських доробків із тестології та різних аспектів застосування тестів у навчанні: О. Авраменко, Т. Андрущенко, П. Атаманчук, О. Барило, І. Булах, О. Виноградов, С. Вітвицька, Ю. Ковальчук, М. Мруга, С. Раков, В. Сергієнко, В. Фетісов, О. Чаркіна, Л. Ярощук та ін. Серед методів об'єктивного контролю найбільш науково обгрунтованим І. Булах, М. Мруга та ін. назвали тестування із залученням технічних засобів для сканування й обробки результатів. Такий підхід пояснюється дидактичними перевагами тестів перед іншими видами перевірки [1].

Окремі наукові праці присвячено і тестуванню студентів зі спеціальності «Початкова освіта». Так, О. Івлієва, О. Варецька, Л. Гаврілова та ін. у своїх дослідженнях навели приклади критеріально-орієнтованого тестування в процесі контролю навченості здобувачів цієї спеціальності $[2 ; 3 ; 4]$. Розвиваючи цю думку, А. Панасюк зауважила, що організація контролю із застосуванням критеріально-орієнтованого тестування дає можливість здобувачам оцінити особисті досягнення і скоректувати власну навчальну діяльність, а викладачам удосконалити процес організації самостійної роботи [6]. О. Чаркіна подала алгоритм організації тестового контролю у викладанні психолого-педагогічних дисциплін, що передбачає певні етапи діяльності [8] тощо.

Відтак у працях науковців обстоюється важливість запровадження тестових технологій у педагогічних вишах, адже воно значно підвищує якість освітнього процесу, зацікавлює здобувачів і мотивує їх на більш глибоке опанування дисципліни. Водночас О. Ішутіна, предметом наукових пошуків якої виступило лінгвометодичне тестування студентів, зазначила, що в практиці роботи моніторинг лінгвометодичної компетентності майбутніх учителів зазвичай не має системного характеру, контроль проводиться розрізнено, наявна одноманітність методів діагностики та недостатня об'єктивність оцінювання тощо [5].

Отже, незважаючи на загалом достатнє висвітлення різноаспектних питань застосування тестових технологій у ЗВО для діагностики розвитку фахових новоутворень майбутніх фахівців освітньої галузі, у вітчизняній науковій 
Тестування в діагностиці розвитку когнітивного компонента готовності майбутніх учителів початкової школи до застосування засобів електронної лінгвометодики в професійній діяльності

літературі бракує теоретичних і практичних досліджень щодо застосування тестових технологій для діагностики розвитку лінгвометодичної компетентності майбутніх учителів початкової школи та іiі окремих складників, зокрема готовності до застосування засобів електронної лінгвометодики в професійній діяльності.

Формулювання цілей статті (постановка завдання). Метою статті $\epsilon$ висвітлення ефективності застосування тестування для виявлення рівня розвитку в студентів ступенів вищої освіти «бакалавр» і «магістр» спеціальності «Початкова освіта» когнітивного компонента готовності до застосування засобів електронної лінгвометодики в професійній діяльності за традиційних умов навчання у 3 ВО.

Теоретичні основи дослідження. Теоретичною основою дослідження виступили традиційні вітчизняні тенденції в підготовці вчителя початкової школи (Н. Бібік, В. Бондар, М. Вашуленко, О. Мельничайко, Н. Ничкало, О. Савченко, Л. Хомич, О. Хорошковська, І. Шапошнікова та ін.), інновації в підготовці фахівців для початкової школи XXI ст. (В. Желанова, Л. Коваль, А. Коломієць, С. Мартиненко, Н. Олефіренко, Л. Петухова, С. Стрілець, О. Ярошинська та ін.), теоретичні засади лінгвометодичної підготовки майбутнього вчителя (М. Вашуленко, Г. Каптур, Н. Остапенко, О. Семеног, О. Копусь, Л. Морська та ін.) та теоретико-методичні основи електронної лінгвометодики (К. Бітті， М. Бовтенко， М. Варшауер， О. Гарцов， Д. Істмент, I. Костікова, Н. Краудер, М. Леві, К. Піотровська, Дж. Томпсон, Ф. Хуббард, Дж. Честер та ін.).

Методика дослідження. Для виявлення рівня розвитку когнітивного компонента готовності до застосування засобів електронної лінгвометодики в професійній діяльності за традиційних умов навчання у ЗВО було виявлено компонентно-рівневу структуру вимірювання готовності майбутнього вчителя початкової школи до застосування засобів електронної лінгвометодики в професійній діяльності, що ілюструє взаємозв'язок і підпорядкованість компонентів цієї готовності (мотиваційно-ціннісний, когнітивний, операційнодіяльнісний, проективний); критеріїв їхнього вимірювання (спрямованість і прагнення, знання, уміння й навички), показників кожного критерію (професійно-особистісні, акмеологічні, лінгвометодичні, соціокультурні, комунікаційні прагнення; теоретико-методичні, лінгвометодичні, проективнометодичні, теоретико-технологічні, технічні, проективно-технологічні знання; методичні, мотиваційні, діагностичні, проективно-методичні, комунікаційні та інші вміння й навички); рівнів опанування майбутніми фахівцями початкової освіти готовності до застосування засобів електронної лінгвометодики в професійній діяльності: інтуїтивно-рецептивний, репродуктивний, продуктивний, дослідницько-креативний.

Дві серії тестів для діагностики рівня розвитку когнітивного компонента готовності студентів бакалавріату та магістратури до застосування засобів 
Тестування в діагностиці розвитку когнітивного компонента готовності майбутніх учителів початкової школи до застосування засобів електронної лінгвометодики в професійній діяльності

електронної лінгвометодики в професійній діяльності за традиційних умов навчання було спрямовано на виявлення обсягу знань про електронну лінгвометодику, ii засоби, методику застосування в початковій школі (для бакалаврів) та ЗВО (для магістрів), розуміння цього матеріалу та здатність його застосовувати в практиці роботи, а також аналізувати теоретичний та практичний лінгвометодичний матеріал, окремі засоби електронної лінгвометодики.

Результати дослідження. У констатувальному тестуванні взяли участь 309 студентів бакалавріату та 112 здобувачів ступеня вищої освіти «магістр» спеціальності «Початкова освіта». У процесі дослідної роботи застосовувалося комп'ютерне тестування студентів. У кожному тесті поєднувалися завдання різних типів, задля чого було використано основні формати тестових завдань закритої та відкритої форм: вибіркові з вибором однієї правильної відповіді, із вибором кількох правильних відповідей, з альтернативною відповіддю «так» «ні»; на відновлення послідовності; на встановлення відповідності; на доповнення поданого речення («коротка відповідь»).

Під час конструювання тестових завдань було дотримано всіх етапів розробки тесту:

1. Сформульовано мету тестування.

2. Дібрано зміст матеріалу, який було включено до тесту (сконструйовано технологічну матрицю тесту).

3. Сформовано банк тестових завдань, який містив близько 100 тестових завдань різних форм і когнітивних рівнів.

4. Сформовано варіант тесту для апробації.

5. Проведено аналіз результатів апробації тесту та здійснено вибраковку тестових завдань.

6. Визначено основні статистичні показники тесту та тестових завдань.

7. Сформовано остаточний варіант тесту для проведення експерименту.

Тестування було організовано з використанням системи дистанційного навчання MOODLE, яка дозволяє реалізувати всі зазначені умови тестування (прогнозувати час для проходження тестування, подавати тестові завдання у випадковому порядку, указувати складність окремих тестових завдань, створювати завдання різних форматів, переглядати статистику та результати тестування) та ефективно налаштовувати різні види тестових завдань. У тестах для здобувачів ступеня вищої освіти «бакалавр» вибіркові формати охоплювали тематику класифікації засобів електронної лінгвометодики для початкової школи, типів слайдів лінгвометодичної презентації на уроці мови, знання вимог щодо організації тестового контролю мовних знань молодших школярів, проектування засобів електронної лінгвометодики тощо (рис. 1).

Вагому частину тематики тестових завдань вибіркових форматів становила також методика застосування засобів електронної лінгвометодики під час опанування різних розділів початкового курсу мови та елементів проектування 
Тестування в діагностиці розвитку когнітивного компонента готовності майбутніх учителів початкової школи до застосування засобів електронної лінгвометодики в професійній діяльності

мультимедійної лінгвометодичної презентації як найбільш використовуваного та доступного засобу електронної лінгвометодики для початкової школи (рис. 2).

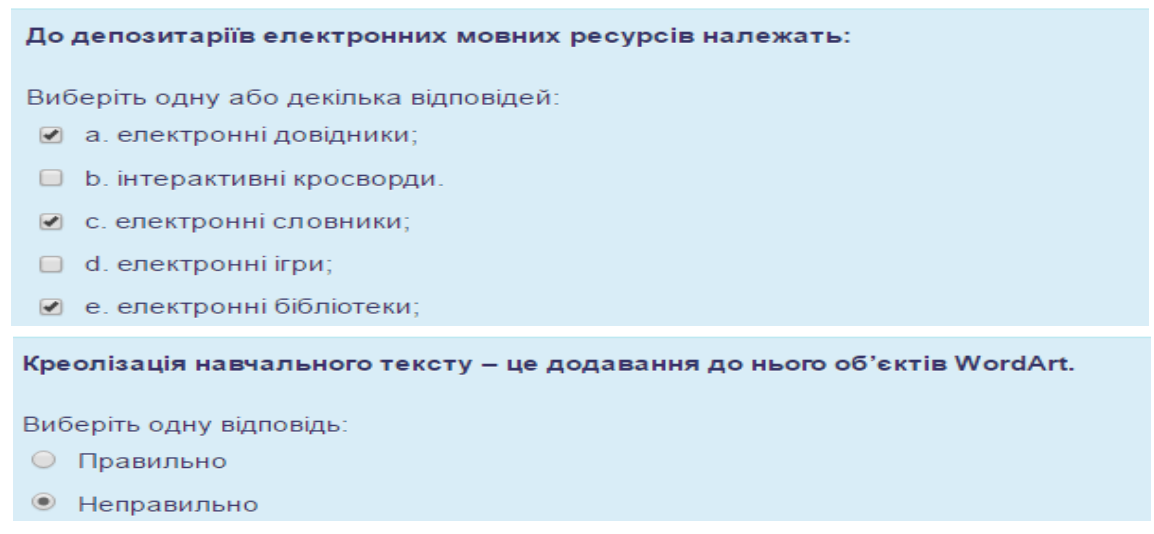

Рис. 1. Приклади тестових завдань вибіркового формату для перевірки знань здобувачів ступеня вищої освіти «бакалавр» щьодо класифікаџіï засобів електронної лінгвометодики та їхнього проектування

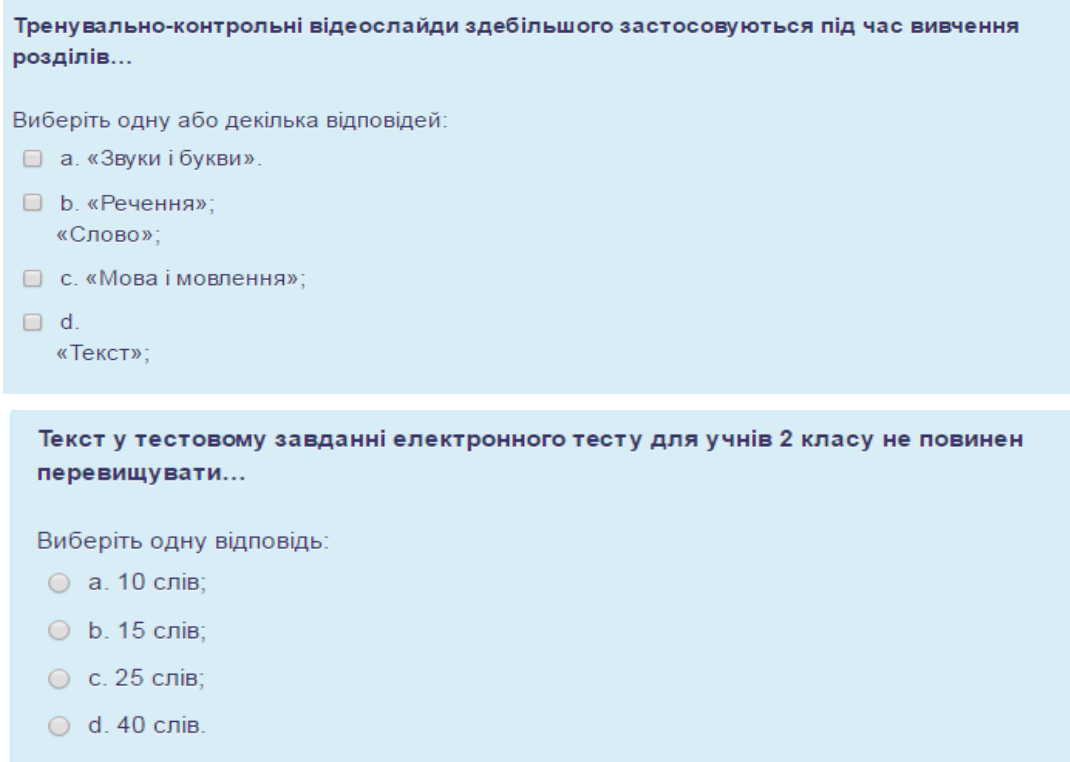

Рис. 2. Приклади тестових завдань вибіркового формату для перевірки знань здобувачів ступеня вищої освіти «бакалавр» щьодо методики застосування засобів електронної лінгвометодики в початковій школі

Аналогічні тематичні напрями було представлено і в тестових завданнях на встановлення відповідності: так перевірялися знання майбутніх бакалаврів початкової освіти щодо класифікації засобів електронної лінгвометодики для початкової школи, програмних середовищ для їхнього проектування, характеристик наявних наразі в Україні педагогічних програмних засобів з мови для початкової школи тощо (рис. 3). 
Тестування в діагностиці розвитку когнітивного компонента готовності майбутніх учителів початкової школи до застосування засобів електронної лінгвометодики в професійній діяльності

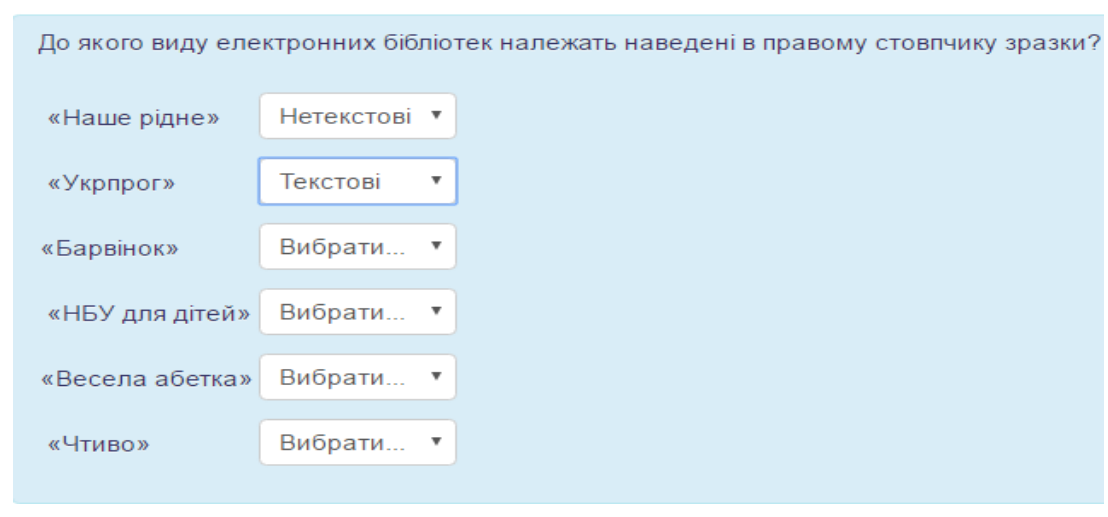

Рис. 3. Приклад тестового завдання на встановлення відповідності для перевірки знань здобувачів ступеня вищої освіти «бакалавр» щзодо характеристик наявних засобів електронної лінгвометодики для молодиих иколярів

Завдання на відновлення послідовності здебільшого діагностували знання щодо методики застосування засобів електронної лінгвометодики в початковій школі: послідовність етапів введення їх у навчальний процес, порядок роботи 3 певним засобом електронної лінгвометодики тощо (рис. 4).

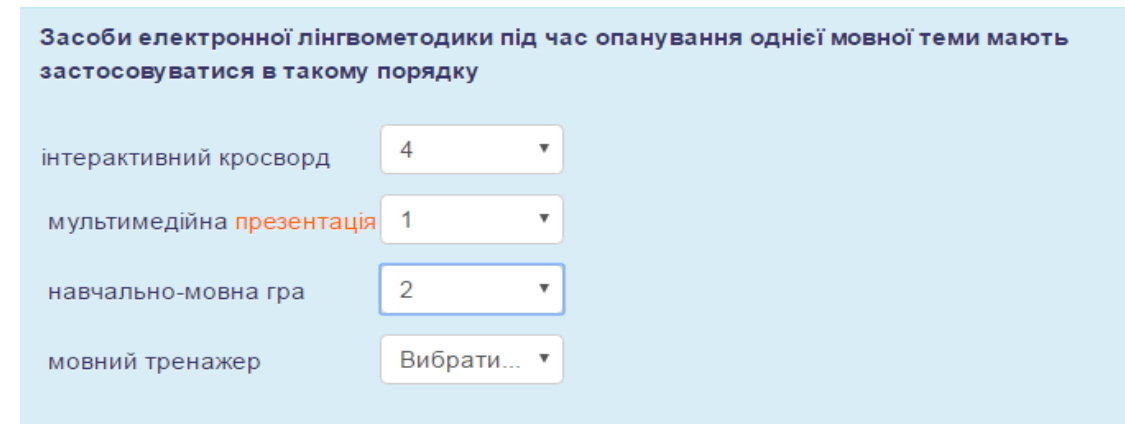

Рис. 4. Приклад тестового завдання на відновлення послідовності для перевірки знань здобувачів ступеня вищої освіти «бакалавр» щодо методики застосування засобів електронної лінгвометодики в освітньому прочесі початкової школи

Завдання відкритої форми типу «вбудовані відповіді» та «коротка відповідь» було спрямовано на перевірку знань здобувачів та вмінь їх аналізувати й застосовувати щодо проектування засобів електронної лінгвометодики, програмних середовищ, які при цьому застосовуються, умінь аналізувати готові засоби електронної лінгвометодики, застосовувати їх під час саморозвитку й самовдосконалення (рис. 5). 
Тестування в діагностиці розвитку когнітивного компонента готовності майбутніх учителів початкової школи до застосування засобів електронної лінгвометодики в професійній діяльності

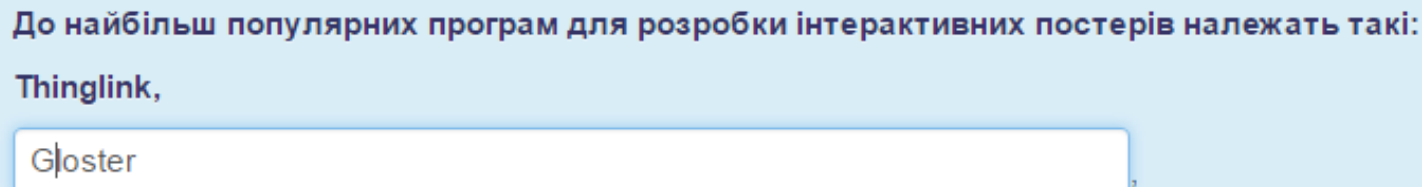

Рис. 5. Приклад тестового завдання відкритого типу для перевірки знань здобувачів ступеня вищої освіти «бакалавр» щэодо проектування засобів електронної лінгвометодики

Кількісний аналіз результатів тестування проводився 3 використанням класичної теорії тестів (Classical Test Theory) за такою схемою:

Крок 1. Визначення показників описової статистики.

Крок 2. Визначення нормальності розподілу результатів тестування.

Крок 3. Визначення показників якості тестових завдань (дискримінативність, складність).

Крок 4. Визначення показників якості тесту (надійність, валідність).

Крок 5. Формування аналітичного звіту за результатами тестування.

Якісний аналіз відповідей на тестові завдання проводився на основі конкретизації змісту показників когнітивного компонента готовності майбутніх учителів початкової школи до застосування засобів електронної лінгвометодики в професійній діяльності (табл. 1).

Таблиця 1.

\section{Зміст показників когнітивного компонента готовності майбутніх учителів початкової школи до застосування засобів електронної лінгвометодики в професійній діяльності}

\begin{tabular}{|c|c|}
\hline Показники & Зміст показника \\
\hline $\begin{array}{c}\text { Лінгвометодичні } \\
\text { знання }\end{array}$ & $\begin{array}{l}\text { знання різновидів засобів електронної лінгвометодики для початкової школи, їх } \\
\text { специфічних особливостей, практичних аспектів методики їх застосування на уроках і в } \\
\text { позаурочній роботі та ін., здатність до їх аналізу й застосування на практиці }\end{array}$ \\
\hline $\begin{array}{l}\text { Теоретико- } \\
\text { технологічні } \\
\text { знання }\end{array}$ & $\begin{array}{l}\text { орієнтування в різновидах інформаційно-комунікаційних технологій, використовуваних у } \\
\text { початковій освіті, здатність до аналізу їх ефективності під час навчання молодших } \\
\text { школярів мови, уміння застосовувати в практичній діяльності }\end{array}$ \\
\hline $\begin{array}{l}\text { Проективні } \\
\text { (методичні та } \\
\text { технологічні) } \\
\text { знання }\end{array}$ & $\begin{array}{l}\text { володіння набором знань і здатностей щодо створення засобів електронної } \\
\text { лінгвометодики для початкової школи, зокрема стосовно дотримання в них методичних } \\
\text { вимог до викладання теоретичних відомостей із різних розділів мовознавства й } \\
\text { формування в учнів відповідних умінь і навичок; опанування алгоритмів створення цих } \\
\text { засобів, перевірки їх ефективності, критеріїв оцінювання якості та ін., розуміння, } \\
\text { здатність до їх аналізу й застосування на практиці }\end{array}$ \\
\hline Технічні знання & $\begin{array}{l}\text { знання програмних середовищ, у яких можна створювати засоби електронної } \\
\text { лінгвометодики для початкової школи, спроможність у них ефективно працювати, } \\
\text { вибирати найбільш доцільне програмне та апаратне забезпечення для викладання певного } \\
\text { мовного змісту тощо; здатність до їх аналізу й застосування на практиці }\end{array}$ \\
\hline
\end{tabular}

Професіоналізм педагога: теоретичні й методичні аспекти. - Вип. 7. - Слов’ янськ, 2018. 
Тестування в діагностиці розвитку когнітивного компонента готовності майбутніх учителів початкової школи до застосування засобів електронної лінгвометодики в професійній діяльності

У результаті аналізу відповідей було з'ясовано, що за традиційних умов навчання, без додаткового опанування елементарних теоретичних засад електронної лінгвометодики здобувачі ступеня вищої освіти «бакалавр» наприкінці навчання здебільшого оволодівають відомостями 3 електронної лінгвометодики практичним шляхом, відповідаючи на вимоги часу, відчуваючи потребу в цьому молодших школярів і вчителів початкової школі, власний досвід опанування лінгвометодики тощо.

Більше за інші групи показників у когнітивному компоненті готовності майбутніх учителів початкової школи до застосування засобів електронної лінгвометодики в професійній діяльності представлено теоретико-технологічний і технічний, бо певний обсяг інформації, яку включають ці показники, студенти бакалавріату опановують під час вивчення інформатики та сучасних інформаційних технологій. Так, більшість правильних відповідей було подано на питання про застосування інфографіки і скрайбінгу в мультимедійних презентаціях (69,6\%), відповідність програмних середовищ засобам електронної лінгвометодики, які в них можна виготовляти (66,3\%), програми, у яких можна розробляти інтерактивні постери $(49,2 \%)$.

Значно менше у відповідях на тестові завдання представлено лінгвометодичні та проективні знання. Найбільше правильних відповідей здобувачі ступеня вищої освіти «бакалавр» подали на питання щодо переважних типів інформації на інформаційно-пояснювальних слайдах під час опрацювання лексики і фразеології (33,0\%), що можна пов’язати з логікою розмірковувань респондентів та наявністю в них загальних лінгвометодичних знань щодо методики опрацювання цих розділів. Лише $29,8 \%$ респондентів засвідчили ознайомлення 3 деякими різновидами засобів електронної лінгвометодики, наявними на ринку педагогічних програмних засобів України, зокрема «Українська мова» («Нова школа») та «Українська мова» («Дитяча колекція»), при цьому «Тренажери грамотності» («Сорока-Білобока») були відомі 17,5\% студентів бакалавріату.

Знання щодо класифікації засобів електронної лінгвометодики для початкової школи, так само як і щодо типів слайдів лінгвометодичної презентації для початкової школи, етапів застосування електронних навчально-мовних ігор тощо перебувають на найнижчому рівні - 4,9\% респондентів засвідчили наявність цих знань, проте досить епізодичних. Здатність проектувати засоби електронної лінгвометодики, відповідно до результатів аналізу відповідей на тестові завдання, грунтується здебільшого на проективно-технологічних знаннях студентів із дисциплін інформатичного циклу. Проективно-методичні знання представлено значно менше. Отже, загальні результати кількісного та якісного аналізу відповідей майбутніх бакалаврів початкової освіти за рівнями сформованості їхньої готовності до застосування засобів електронної лінгвометодики в професійній діяльності виглядають так (табл. 2). 
Тестування в діагностиці розвитку когнітивного компонента готовності майбутніх учителів початкової школи до застосування засобів електронної лінгвометодики в професійній діяльності

Відтак більшість бакалаврів початкової освіти на момент завершення навчання мають репродуктивний рівень сформованості когнітивного компонента готовності до застосування засобів електронної лінгвометодики в професійній діяльності, що передбачає загальну наявність лінгвометодичних знань, проте з незначними недоліками, а також елементарних проективних знань, що загалом відповідають змісту навчальної програми.

Таблиця 2.

\section{Рівні сформованості когнітивного компонента готовності майбутніх бакалаврів початкової освіти до застосування засобів електронної лінгвометодики в професійній діяльності}

\begin{tabular}{|c|c|c|c|}
\hline $\begin{array}{c}\text { Інтуїтивно- } \\
\text { рецептивний }\end{array}$ & Репродуктивний & Продуктивний & $\begin{array}{c}\text { Дослідницько- } \\
\text { креативний }\end{array}$ \\
\hline $31,7 \%$ & $53,4 \%$ & $10,0 \%$ & $4,9 \%$ \\
\hline
\end{tabular}

Теоретико-технологічні та проективно-технологічні знання цих студентів представлено в обмеженому обсязі, технічні - у достатньому, відповідному навчальній програмі з базового курсу лінгвометодики.
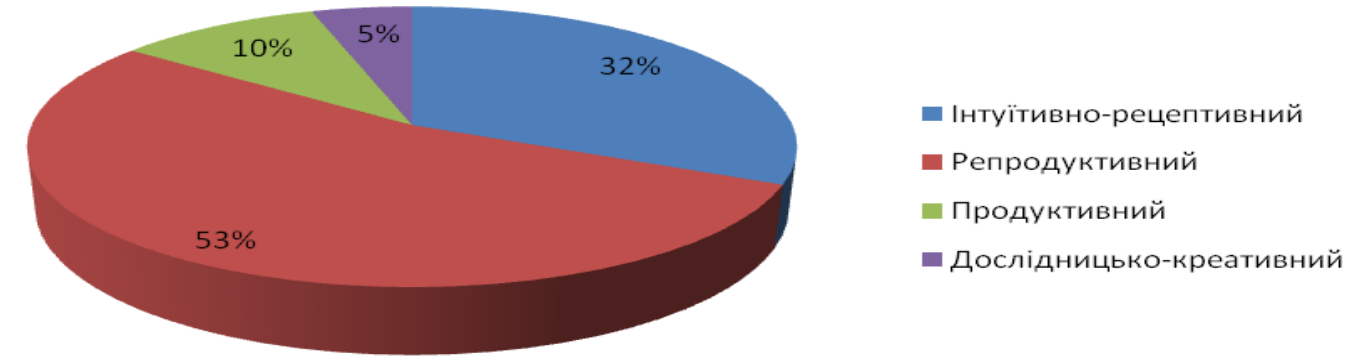

Рис. 6. Рівні сформованості когнітивного компонента готовності майбутніх бакалаврів початкової освіти до застосування засобів електронної лінгвометодики

Значна частина випускників бакалавріату, що мають інтуїтивнорецептивний рівень сформованості готовності до застосування засобів електронної лінгвометодики в професійній діяльності, опановують відомості про електронну лінгвометодику принагідно, лише за прямої необхідності, керуючись при цьому наявними в мережі Інтернет готовими зразками, почасту не усвідомлюючи різноманітності засобів електронної лінгвометодики, специфіку кожного з них, методичні особливості застосування й проектування тощо.

Найменша кількість майбутніх учителів початкової школи, що засвідчили продуктивний $(10,0 \%)$ та дослідницько-креативний (4,9\%) рівні сформованості когнітивного компонента готовності до застосування засобів електронної лінгвометодики в професійній діяльності надає підстави зробити висновок, що за стихійного опанування засобів електронної лінгвометодики лише незначна частина бакалаврів початкової освіти самостійно досліджують цей матеріал, що 
Тестування в діагностиці розвитку когнітивного компонента готовності майбутніх учителів початкової школи до застосування засобів електронної лінгвометодики в професійній діяльності

вказує на нагальну потребу його введення до навчальної програми базового курсу «Методика навчання української мови в початковій школі».

Тестування майбутніх магістрів початкової освіти відбувалося аналогічно до бакалаврів наприкінці терміну навчання й мало подібні ознаки щодо використовуваних форматів тестових завдань (рис. 7).

Тематика цих завдань була дещо відмінною від попереднього тестування: по-перше, вона стосувалася використання засобів електронної лінгвометодики у вищій освіті під час підготовки майбутніх учителів початкової школи, по-друге, містила більше завдань, спрямованих на перевірку теоретичних знань магістрантів з електронної лінгвометодики (рис. 8), тоді як тести для бакалаврів більше спрямовувалися на виявлення знань щодо практичних аспектів електронної лінгвометодики.

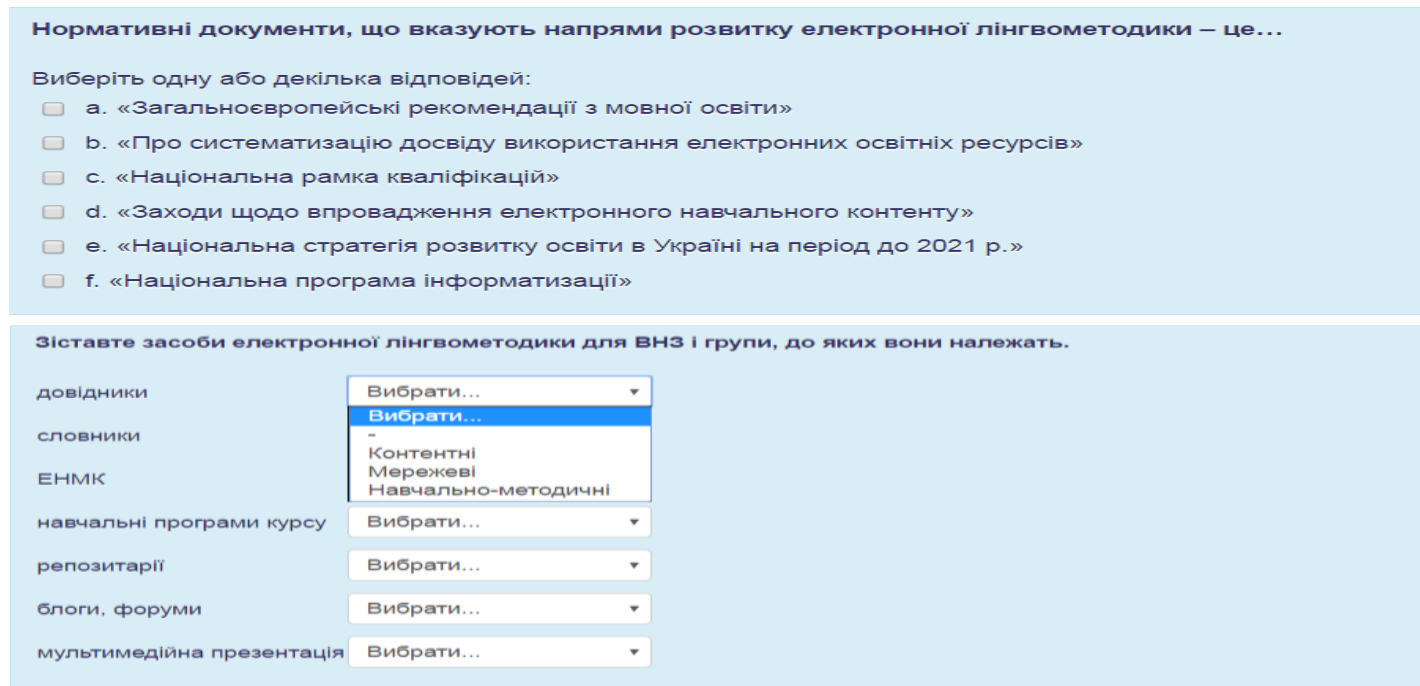

Рис. 7. Приклади тестових завдань для перевірки знань здобувачів ступеня вищої освіти «магістр»

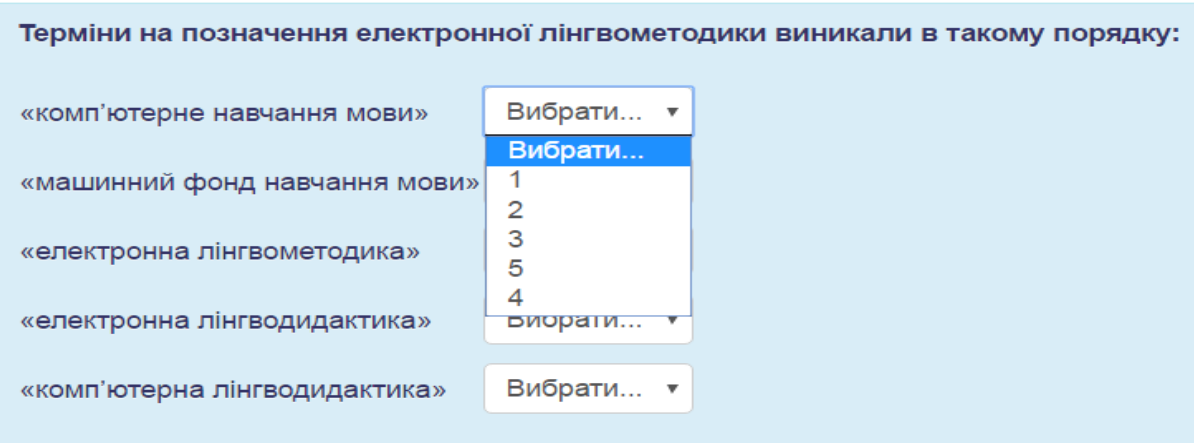

До психологічних засад застосування засобів електронної лінгвометодики належать такі: біхевіоризм, теорія поетапного формування розумових дій, когнітивна психологія,

Рис. 8. Приклади тестових завдань для перевірки знань здобувачів ступеня вищої освіти «магістр» щуодо теоретичних засад електронної лінгвометодики 
Тестування в діагностиці розвитку когнітивного компонента готовності майбутніх учителів початкової школи до застосування засобів електронної лінгвометодики в професійній діяльності

Якісний аналіз відповідей на тестові завдання проводився на основі критеріїв когнітивного компонента готовності майбутніх учителів початкової школи до застосування засобів електронної лінгвометодики в професійній діяльності, проте, на відміну від його діагностики в майбутніх бакалаврів, у магістрантів додавався ще й теоретико-методичний критерій, що полягав у володінні та оперуванні теоретичними знаннями з електронної лінгвометодики.

У результаті діагностики було з'ясовано, що за традиційних підходів до навчання лінгвометодичних дисциплін наприкінці навчання в магістратурі майбутні вчителі початкових класів та викладачі методики навчання мови в початковій школі мають певний обсяг знань про електронну лінгвометодику та iii засоби для початкової школи та ЗВО, проте у відповідній термінології орієнтуються лише $19,6 \%$ респондентів.

Серед засобів електронної лінгвометодики для ЗВО найбільш відомим і опанованим студентами магістратури залишається мультимедійна презентація $83,0 \%$, поняття ж наукових репозитаріїв, онлайн-сервісів для створення засобів електронної лінгвометодики, відкритих освітніх ресурсів, інфографіки, скрайбінгу та інших технологій, використовуваних у цих засобах, відоме досить незначному відсотку магістрантів - 14,3\%. Дещо більший обсяг знань виявився щодо нормативних підвалин електронної лінгвометодики - відповідні закони, постанови та листи були відомі 66,1\% респондентів.

Водночас аналіз відповідей на питання практичного характеру засвідчив, що здебільшого майбутні викладачі методики навчання української мови в початковій школі орієнтуються в методиці створення та застосування на заняттях загальновідомих різновидів засобів електронної лінгвометодики (мультимедійні презентації, тести, ЕНМК) - 87,5\%; володіють необхідним обсягом знань для роботи з програмними засобами електронної лінгвометодики (перекладачі, словники, довідники, текстові редактори тощо) - 91,1\%. Практично відсутні в респондентів знання стосовно сучасних світових досягнень у галузі електронної лінгвометодики, різновидів інтернет-видань та сайтів - 8,0\%.

Загалом результати тестування для діагностики когнітивного компонента готовності майбутніх викладачів методики навчання мови до застосування засобів електронної лінгвометодики в професійній діяльності за рівнями розподілилися так (табл. 3).

Таблиця 3.

Рівні сформованості когнітивного компонента готовності майбутніх магістрів початкової освіти до застосування засобів електронної лінгвометодики в професійній діяльності

\begin{tabular}{|c|c|c|c|}
\hline $\begin{array}{c}\text { Інтуїтивно- } \\
\text { рецептивний }\end{array}$ & Репродуктивний & Продуктивний & $\begin{array}{c}\text { Дослідницько- } \\
\text { креативний }\end{array}$ \\
\hline $16,8 \%$ & $55,1 \%$ & $19,7 \%$ & $8,4 \%$ \\
\hline
\end{tabular}


Тестування в діагностиці розвитку когнітивного компонента готовності майбутніх учителів початкової школи до застосування засобів електронної лінгвометодики в професійній діяльності

Як бачимо, за традиційних умов навчання лінгвометодики у виші на ступені вищої освіти «магістр» студенти частково просуваються у розвитку власної лінгвометодичної діяльності за рахунок практичного опанування засобів електронної лінгвометодики, проте мають значні прогалини у відповідній теоретичній базі, що заважає їм на сучасному рівні ефективно організовувати власну професійну діяльність, наукові пошуки, прагнення саморозвитку та самовдосконалення (рис. 9).

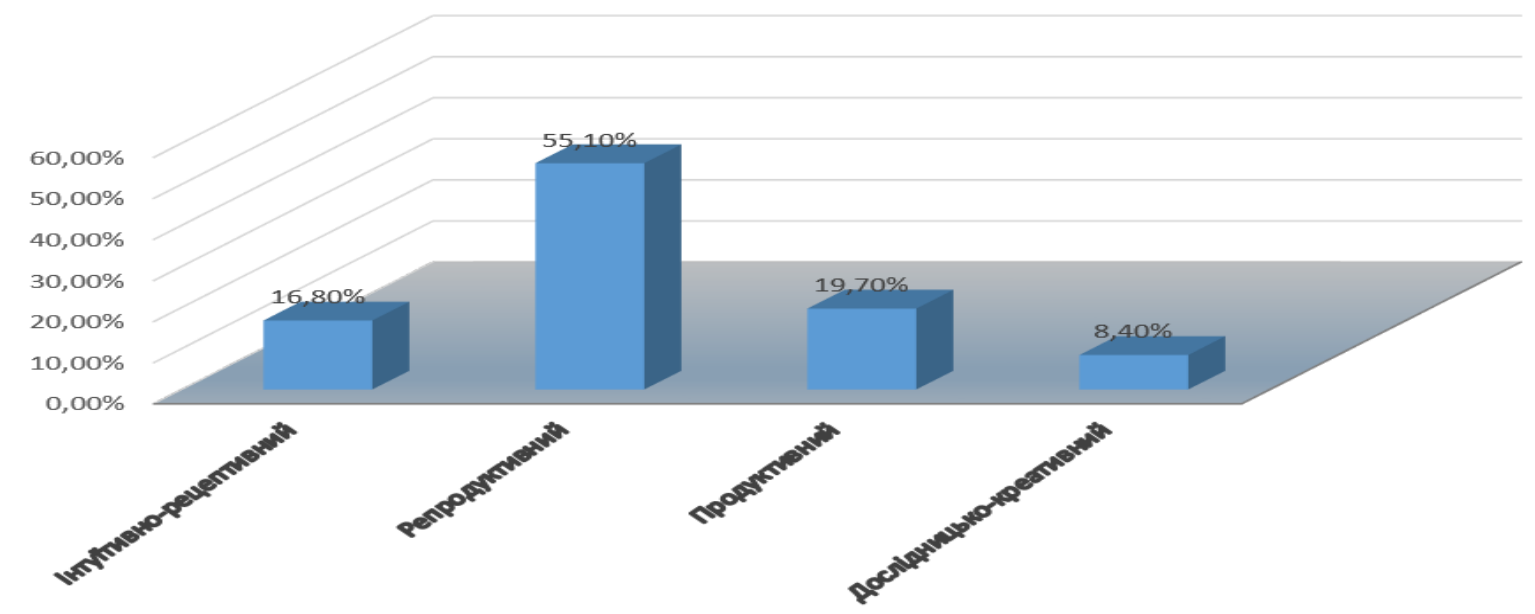

Рис. 9. Рівні розвитку когнітивного компонента готовності магістрів до застосування засобів електронної лінгвометодики в професійній діяльності

Висновки $з$ дослідження і перспективи подальших розвідок у цьому напрямі. Отже, підсумовуючи результати емпіричного дослідження, спрямованого на виявлення рівня сформованості когнітивного компонента готовності майбутніх фахівців початкової освіти до застосування засобів електронної лінгвометодики в професійній діяльності, можна зауважити що, поперше, тестування виявилося релевантним методом вимірювання відповідного особистісного феномена майбутніх учителів, вірогідність результатів якого доводиться числовими показниками; по-друге, за умов традиційного навчання лінгвометодики в більшості майбутніх фахівців у галузі початкової освіти (i бакалаврів, і магістрів) переважає репродуктивний рівень розвитку когнітивного компонента готовності, проте другим за чисельністю в бакалаврів є інтуїтивнорецептивний рівень, а в магістрів - продуктивний, що, на наш погляд, відбиває загальну динаміку фахового зростання впродовж навчання на бакалавріаті.

Важливим показником є мінімальна кількість респондентів, які виявили приналежність до дослідницько-креативного рівня, що прямо вказує на необхідність системного опанування основ електронної лінгвометодики на бакалаврському та магістерському ступенях вищої освіти. До перспектив подальших пошуків у цьому напрямі відносимо визначення найбільш доцільних методів для вимірювання рівня розвитку інших компонентів готовності майбутніх фахівців початкової освіти до застосування засобів електронної 
Тестування в діагностиці розвитку когнітивного компонента готовності майбутніх учителів початкової школи до застосування засобів електронної лінгвометодики в професійній діяльності

лінгвометодики в професійній діяльності та їхню безпосередню діагностику в майбутніх фахівців початкової освіти.

\title{
СПИСОК ВИКОРИСТАНИХ ДЖЕРЕЛ
}

1. Булах, I. С. і Мруга, М. Р. (2006). Створюємо якісний тест. Київ, Україна: Майстерклас.

2. Варецька, О. В. (2016). Критерії, показники та рівні розвитку діяльнісного компонента соціальної компетентності вчителя початкової школи в системі післядипломної педагогічної освіти. Професіоналізм педагога: теоретичні й методичні аспекти, 4, 25-37. Взято 3 http://pptma.dn.ua/files/2016/4/3.\%20Varetska_S.25-37.pdf

3. Гаврілова, Л. Г. (2015). Науково-методологічні підходи до аналізу професійної компетентності майбутніх учителів початкових класів. Професіоналізм педагога: теоретичні й методичні аспекти, 2, 7-17. Взято 3 http://pptma.dn.ua/files/2015/2/3.gavrilova.7-17.pdf

4. Івлієва, О. М. (2001). Критеріально-орієнтоване тестування в системі формування професійної готовності вчителя початкових класів. (Автореф. дис. канд. пед. наук). Одеса, Україна: Південноукраїнський державний педагогічний імені К. Д. Ушинського.

5. Ішутіна, О. Є. (2016). Вивчення стану організації лінгвометодичного моніторингу у вишах України. Професіоналізм педагога: теоретичні й методичні аспекти, 4, 25-37. Взято 3 http://pptma.dn.ua/files/2017/6/16.\%20Ishutina\%20137-149.pdf

6. Панасюк, А. В. (2009). Організація тестового контролю з іноземної мови у процесі самостійної навчальної діяльності здобувачів вищих технічних навчальних закладів. (Автореф. дис. канд. пед. наук). Житомир, Україна: ЖДУ імені І. Франка.

7. Спірін, О. М. (2007). Теоретичні та методичні засади професійної підготовки майбутніх учителів інформатики за кредитно-модульною системою. М. І. Жалдак (Ред.). Житомир, Україна: Вид-во ЖДУ імені І. Франка.

8. Чаркіна, О.А. (2009). Педагогічне тестування як засіб контролю за навчальним проиесом у педагогічних університетах. (Автореф. дис. канд. пед. наук). Кривий Ріг, Україна: Криворізький державний педагогічний університет.

\section{ТЕСТИРОВАНИЕ В ДИАГНОСТИКЕ РАЗВИТИЯ КОГНИТИВНОГО КОМПОНЕНТА ГОТОВНОСТИ БУДУЩИХ УЧИТЕЛЕЙ НАЧАЛЬНОЙ ШКОЛЫ К ПРИМЕНЕНИЮ СРЕДСТВ ЭЛЕКТРОННОЙ ЛИНГВОМЕТОДИКИ В ПРОФЕССИОНАЛЬНОЙ ДЕЯТЕЛЬНОСТИ}

\author{
Инна Хижняк \\ доктор педагогических наук, профессор, \\ декан факультета начального, технологического и \\ профессионального образования, \\ ДВНЗ «Донбасский государственный педагогический университет» \\ м. Славянск Донецкой обл., Украина \\ http://orcid.org/0000-0002-4227-8268 \\ innakhieshn@gmail.com
}

Аннотация. В статье обосновывается важность диагностики развития профессиональных новообразований будущего специалиста, одним из которых для учителя начальной школы выступает готовность к применению средств электронной лингвометодики в профессиональной деятельности, и использования при этом метода тестирования. В

Професіоналізм педагога: теоретичні й методичні аспекти. - Вип. 7. - Слов’янськ, 2018. 
Тестування в діагностиці розвитку когнітивного компонента готовності майбутніх учителів початкової школи до застосування засобів електронної лінгвометодики в професійній діяльності

процессе исследования этой готовности у будущих учителей начальной школы автор опирается на мощную теоретическую базу, в которую вошли традиционные отечественные тенденции в подготовке учителя начальной школы, инновации в подготовке специалистов для начальной школы XX в., теоретические основы лингвометодической подготовки будущего учителя и теоретико-методические основы электронной лингвометодики. В статье автор пришла к выводу, что тестирование является релевантным методом измерения соответствующего личностного феномена будущих учителей и в условиях традиционного обучения лингвометодики у большинства будущих специалистов в области начального образования (и бакалавров, и магистров) преобладает репродуктивный уровень развития когнитивного компонента готовности, а минимальным является количество респондентов, выявивших принадлежность к опытно-креативному уровню. Эти показатели позволили автору указать на необходимость системного освоения основ электронной лингвометодики на бакалаврской и магистерской ступенях высшего образования.

Ключевые слова: педагогическая диагностика; тестирование; электронная лингвометодики; лингвометодични компетентность; готовность к применению средств электронной лингвометодики в профессиональной деятельности; учитель начальной школы.

\title{
TESTING IN THE DIAGNOSTICS OF COGNITIVE COMPONENT DEVELOPMENT OF FUTURE PRIMARY SCHOOL TEACHERS' READINESS FOR USING ELECTRONIC LINGUOMETHODOLOGICAL TOOLS IN THE PROFESSIONAL ACTIVITY
}

\author{
Inna Khyzhnyak \\ Doctor of Pedagogical Sciences, Professor, \\ Dean of the Primary, Technology and Vocational Education Department, \\ SHEE "Donbass State Pedagogical University", \\ Sloviansk, Donetsk region, Ukraine \\ http://orcid.org/0000-0002-4227-8268 \\ innakhieshn@gmail.com
}

Abstract. The article substantiates the importance of diagnosing the development of a future specialist's professional skills, one of which for a primary school teacher is the readiness to use the tools of electronic linguomethodology in the professional activity and use the method of testing in this process. While studying the level of development of future primary school teachers' readiness, the author relies on a strong theoretical basis, which includes traditional national trends in primary school teachers' training, innovations in training the specialists for the primary school of the XXI century, the theoretical foundations of linguomethodological training the future teacher and the theoretical and methodological framework of electronic linguomethodology. Research methodology is based on the author's component and level structure of measuring the future primary school teachers' readiness to use the tools of electronic linguomethodology in their professional activities, which illustrates the relationship and subordination of components of the readiness, criteria for their measurement, indicators of each criterion and future primary education specialists' levels of mastering.

To conduct an empirical study, the author has developed two series of tests for the measuring the level of the cognitive component of the readiness of bachelor and master students to apply electronic linguomethodological tools in their professional activities in the traditional learning environment. As a result of the analysis of the responses to the test tasks, the author has found that a significant number of the bachelor and master graduates use the information about the electronic 
Тестування в діагностиці розвитку когнітивного компонента готовності майбутніх учителів початкової школи до застосування засобів електронної лінгвометодики в професійній діяльності

linguomethodology, as well as ready-made samples available on the Internet, partly being unaware of the variety of electronic linguomethodological tools, their specifics, methodological features of the application and design etc. In the article the author concludes that testing is a relevant method for measuring this personal phenomenon of future teachers and under the conditions of traditional teaching linguomethodology most future specialists in the field of primary education (bachelors and masters) have the reproductive level of development of the cognitive component of readiness, and the number of respondents who has the research and creative level is minimum. These indicators allow the author to point out the need for systematic mastering of the basics of electronic linguomethodology at the bachelor's and master's levels of higher education.

Key words: pedagogical diagnostics; testing; electronic linguomethodology; linguomethodological competence; readiness for using tools of electronic linguomethodology in professional activity; a primary school teacher.

\section{REFERENCES}

1. Bulakh, I. Ye., \& Mruha, M. R. (2006). We create a qualitative test. Kyiv, Ukraine: Maister-klas.

2. Varetska, O. V. (2016). Criteria, Indicators and Levels of the Competence of the Primary School Teacher Active Component Development in the System of Postgraduate Pedagogical Education. Profesionalizm pedahoha: teoretychni y metodychni aspekty, 4, 25-37. Retrieved from http://pptma.dn.ua/files/2016/4/3.\%20Varetska_S.25-37.pdf

3. Havrilova, L. H. (2015). Scientific and methodological approaches to the analysis of the future primary school teachers professional competence. Profesionalizm pedahoha: teoretychni $y$ metodychni aspekty, 2, 7-17. Retrieved from http://pptma.dn.ua/files/2015/2/3.gavrilova.7-17.pdf

4. Ivliieva, O. M. (2001). Criterio-oriented testing in the system of formation the elementary school teacher's professional readiness. (Extended abstract of $\mathrm{PhD}$ dissertation). Odesa, Ukraine: Pivdennoukrainskyi derzhavnyi pedahohichnyi imeni K. D. Ushynskoho.

5. Ishutina, O. Ye. (2016). Implementing project technology into monitoring of prospective Ukrainian language teachers' linguomethodological competence. Profesionalizm pedahoha: teoretychni y metodychni aspekty, 4, 25-37. Retrieved from http://pptma.dn.ua/files/2017/6/16.\%20Ishutina\%20137-149.pdf

6. Panasiuk, A. V. (2009). Foreign Language Test Control Organization in the Process of Students' Individual Activity of Higher Technical Educational Establishments. (Extended abstract of PhD dissertation). Zhytomyr, Ukraine: ZhDU imeni I. Franka.

7. Spirin, O. M. (2007). Theoretical Methodical Principles of Vocational Training of Future Teachers of Informatics under the Credit-Module System. M. I. Zhaldak (Ed.). Zhytomyr, Ukraine: Vyd-vo ZhDU imeni I. Franka.

8. Charkina, O. A. (2009). Pedagogical testing as control method of an educational process in pedagogical universities. (Extended abstract of $\mathrm{PhD}$ dissertation). Kryvyi Rih, Ukraine: Kryvorizkyi derzhavnyi pedahohichnyi universytet.

Матеріали надійшли до редакції 08.04.2018 р. 